ELORE (ISSN 1456-3010), vol. 19 - 2/2012.

Julkaisija: Suomen Kansantietouden Tutkijain Seura ry.

[http://www.elore.fi/arkisto/2_12/hakamies.pdf]

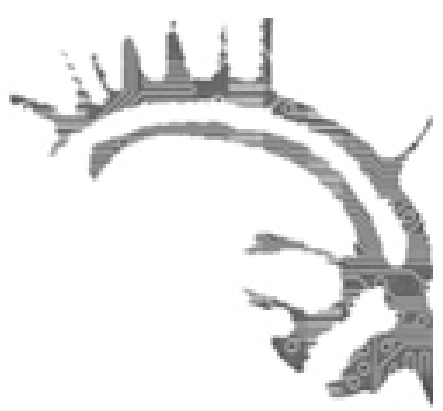

\title{
EMINENTIA-LIITE
}

\section{EMINENTTIÄ FOLKLORISTIIKKAA}

\author{
Pekka Hakamies
}

Toukokuun 15. päivä pidetyssä Suomen Kansantietouden Tutkijain Seuran kevätkoulussa esiintyi aiemmista poiketen neljä varttunutta tutkijaa, jotka pitivät Eminentia-luennot. Kullakin esiintyjällä oli oma aiheensa ja näkökulmansa, ja luennot kattoivatkin laajalti folkloristiikan kenttää. Seuraava teksti ei ole niinkään luentojen referointia kuin niiden herättämien ajatusten esittelyä. Satu Apon, Aili Nenolan ja Seppo Knuuttilan esitykset ovat luettavissa tässä Eloren numerossa omana Eminentia-liitteenään.

Suomalaisen Kirjallisuuden Seuran (SKS) kansanrunousarkiston emeritusjohtaja Pekka Laaksonen kuvasi luennossaan, miten muistitieto tuli klassisen, kiinteätekstisen folkloren ohella järjestelmällisen keruun ja tutkimuksen kohteeksi. Osaksi kyseessä on ollut tieteen sisäinen muutos, jota rakennettiin ennen kaikkea pohjoismaisessa Vöyrin kenttätyöseminaarissa kesällä 1965. Sen myötä tutkimuksen mielenkiinto siirtyi kertomuksista kertojiin ja kerrontaan prosessina.

Kansanrunoudentutkimuksella, sittemmin folkloristiikalla, on aina ollut tiiviit suhteet yhteiskuntaan, vaikka asiaa ei aina olekaan tiedostettu. Kansallisvaltion rakentamisen aikana Kalevala, eeppinen kansanrunous ja muu kansallista menneisyyskuvaa tuottanut tutkimus on ollut yhteiskunnallisesti relevanttia. Modernisaation myötä 1960-luvulla kansallisen folkloristiikan rinnalle tuli vähitellen keruu sekä tutkimus, joka hyödynsi nuorempia aineistoja eikä enää nähnyt folkloren tuottajana yhtenäistä kansaa vaan erilaisia yhteiskunnallisia ryhmiä. Samalla ryhmien tuottama muistitieto juuri heidän omana menneisyyskuvanaan tuli tärkeäksi. Romanien suullisen perinteen dokumentointi ja esittely äänilevyllä toi esiin ensimmäistä kertaa etnisen vähemmistön, joka ei ollut sillä tavalla keskeinen kansallisen kertomuksen kannalta kuin saamelaiset tai suomenruotsalaiset. 
Muutos ei ollut helppo. Suomalaisen Kirjallisuuden Seurassa oli jyrkästi erilaisia näkemyksiä siitä, oliko syytä kerätä vuoden 1918 muistitietoa. Hanke lopulta toteutettiin, ja siitä muodostui merkkipaalu kansanrunousarkiston keruupolitiikassa. Vuoden 1918 muistitietohanketta seurasi melko pian jätkäperinteen keruu. Vaikka Matti Kuusi ylistikin keruun tuottamista aineistoista toimitetun antologian esipuheessa kirjoittajien lahjakkuutta, itse aineisto katsottiin SKS:n piirissä niin ruokottomaksi, että kirja piti antaa muualle julkaistavaksi. Samoin kävi rakentajaperinteestä toimitetulle teokselle, mutta sen jälkeen SKS on julkaissut omista kilpakeruistaan toimitetut antologiat.

Teema- tai ryhmäkohtaisen muistitiedon keruu, aineiston arkistoiminen ja antologian julkaiseminen yhteistyönä ulkopuolisten tahojen kanssa on ollut yhteiskunnallista vuorovaikutusta jo kauan ennen kuin sellaisesta ruvettiin humanistisen tutkimuksen yhteydessä puhumaan. Monet keruuhankkeista ovat toteutuneet alun perin yhteiskunnasta tulleen ehdotuksen pohjalta. Folkloristien kesti jonkin aikaa tottua siihen, että henkilökohtainen muistelukerronta oli sellaisenaan oikeaa tutkimusaineistoa eikä pelkästään kontekstitietoja, joita oli ruvettu noteeraamaan 1960-luvulla. Muistan Pekka Laaksosen joskus vuosikymmeniä sitten todenneen muistitietoaineistosta, että sitä käyttivät yhteiskuntatieteilijät paljon enemmän kuin folkloristit.

Satu Apon luento käsitteli toisella tavalla folkloristiikan olemusta ja perimmäisiä kysymyksiä. Satuja ja etenkin ihmesatuja on totuttu pitämään folkloristiikan kuningaslajina epiikan ohella, ja ihmesaduissa on nähty monenlaisia kajastuksia menneiltä vuosituhansilta ja ihmissielun syvyyksistä, eurooppalaisen keskiajan ohella. Kun tällaisen perinnelajin perusteisiin kajotaan kieltämällä sen suullinen alkuperä ja ikivanha historia, ollaan tekemisissä aika suurten asioiden kanssa. Ruth Bottigheimer on omilla perusteillaan kiistänyt ihmesatujen perusluonteen suullisena perinteenä väittämällä näitä satuja alkuperältään kirjallisiksi ja Euroopassa uudella ajalla luoduksi traditioksi, joka on sittemmin levinnyt laajalti suullisesti. Reaktiot ovat olleet kiivaita, Satu Apo toi hyvin esiin sen, kuinka suuria tunteita Bottigheimerin näkemys on herättänyt muiden tutkijoiden keskuudessa.

Aili Nenola esitti laajana kaarena suomalaisen naisasialiikkeen historian ja sen yhteydessä feministisen näkökulman muodostumisen folkloristiikkaan; nykyään on paikallaan puhua sukupuolinäkökulmasta. Feministinen tutkimus on sikäli poikkeuksellinen tieteen kentällä, että siihen on alusta lähtien liittynyt selkeä yhteiskunnallinen missio: naisten sorretun aseman paljastaminen ja sortoa ylläpitävien rakenteiden ja mekanismien analysointi. Naistutkimus onkin herättänyt 2000 -luvulla enemmän intohimoja ja väittelyjä kuin mikään muu tutkimuksen suuntaus.

Tuskin kukaan kiistää naisnäkökulman edustajien mission oikeutusta. Naistutkimus on vuosien mittaan haaronut moniaalle, eivätkä kaikki suuntauksen alle itsensä sijoittavat ole ehkä perusasioistakaan aivan samaa mieltä. Yhteistä on tietty konstruktionistisuus ja siihen luonnostaan liittyvä relativismi, jolloin tiedon katsotaan olevan sidoksissa sen esittäjän näkökulmaan. Radikaaleimmillaan naistutkijat ovat nähneet oman tutkimusalansa perustavanlaatuisesti erilaisena kuin “miestieteen”, eikä näiden kahden vertailu ole sen vuoksi mahdollista. Maltillisempi naistutkimus lähtee samoista tieteenfilosofisista perusteista kuin muukin tutkimus ja löytää oman suuntansa ennen kaikkea tutkimuskohteiden ja -kysymysten valinnassa. Tiedollinen relativismi ja konstruktionismi ovat 
olleet valtasuuntauksia viime vuosikymmeninä ihmistieteissä, ja harva tutkija on ääneen vannonut realismin nimeen. Johonkin mittaan tällainen on perusteltua, mutta mitä enemmän sijaa annetaan relativistiselle epäilylle, sitä vaikeammaksi käy yhteisen arviointipohjan löytäminen eri suuntauksille. Olisi sääli, jos nais- ja miestiede eivät kykenisi keskustelemaan keskenään.

Seppo Knuuttila lähti luennossaan liikkeelle toisenlaisesta tiedollisen relativismin ongelmasta ja havainnollisti asiaa kysymällä, mistä oikein on kyse kun tutkittava puhuu haltiakokemuksistaan ja tutkija pohtii, mitä haastateltavan kertomasta on olemassa ja mitä ei - kuten Honko aikanaan kysyi, kuinka tutkia sitä mitä ei ole oikeasti olemassa. Ajankohtaisesta tutkimuksesta ja tämän ongelman tiedostamisesta Knuuttila mainitsi esimerkkinä Pasi Engesin väitöskirjan; väittelyn lektion teksti julkaistaan tässä Eloren numerossa. Tutkijoiden perinteinen lähestymistapa on on ollut rationaalisen selityksen löytäminen. Knuuttila näki tällaisen näkökulman juuret antiikin traditiossa. Suomalaisessa tutkimuksessa Simonsuuren teos Myytillisiä tarinoita on hyvä esimerkki siitä, kuinka tutkija ensin esittelee uskomustarinoita ja sen jälkeen pohtii sitä, millaiset todellisuuden ilmiöt ovat voineet synnyttää näitä tarinoita.

Vaihtoehtoinen, nykyään yleistynyt tutkijoiden asenne on relativistinen hyväksyntä sille, että tällaisia uskomuksia on oikeasti olemassa ja kokemukset ovat tutkittaville todellisia. Sen sijaan tutkija jättää silleen sen pohtimisen, mikä todellisuudessa on synnyttänyt uskomukset. Knuuttila siirtyi välillä pohtimaan relativismin asemaa yleensä ja etenkin niin sanottua jyrkkää relativismia. Sitä vastaan on usein hyökätty, ja relativismin kannattajat ovat vastanneet kysymällä, missä oikein on se jyrkkä relativismi, joka on kriitikoiden maalitauluna. - Uskoakseni jyrkän relativismin puuttuminen empiirisistä tutkimuksista johtuu sen perustavanlaatuisesta ongelmallisuudesta. Koko ajatus lienee elänyt lähinnä teoreetikkojen julistuksissa, ilman että kukaan olisi pyrkinyt tekemään tutkimusta siltä pohjalta.

Todellinen ongelma on se, kuinka tutkija voi yhtäältä etnografiassaan ymmärtää tutkittavaa ja hyväksyä hänen argumentaationsa ja maailmankuvansa ja toisaalta säilyttää oman tieteellisen ajattelutapansa. Luonteva ratkaisu voisi olla sellainen relativismin ja realismin yhdistelmä, jota on käytetty ainakin suullisen historian parissa. Menneisyyskuvat siten kuin ihmiset niistä kertovat voivat olla ristiriidassa sen kanssa, mitä historian faktoista tunnetaan. Ne ovat kuitenkin psykologisesti tosia, kuten Alessandro Portelli kirjoittaa teoksessaan The order has been carried out : history, memory, and meaning of a Nazi massacre in Rome (2003), niiden olemassaolo sinänsä on tosiasia ja ne vaikuttavat ihmisten ajatteluun ja toimintaan. Lopulta voi olla tutkimuksen kannalta antoisampaa selvittää sitä, millaiset historialliset rakenteet ja psykologiset mekanismit ovat synnyttäneet tosiasioiden kanssa virheellisiä mielikuvia ja muistoja, kuin että tyydyttäisiin vain toteamaan, että tällaisiakin on - ja jätettäisiin silleen.

Pekka Hakamies on Turun yliopiston folkloristiikan professori ja Turun yliopiston humanistisen tiedekunnan historian, kulttuurin ja taiteiden tutkimuksen laitoksen johtaja. Lisäksi hän on Suomalaisen Kirjallisuuden Seuran hallituksen jäsen. 